\title{
Observations on the review body's 1983 report
}

J C FORD

The thirteenth report of the review body on doctors' and dentists' remuneration, which was published last month, ${ }^{1}$ is potentially very important for several reasons. Coming hard on the heels of the second stage of settlements for National Health Service workers, which provided for $4 \frac{1}{2} \%$ increases during the year $1983-4^{2}$ and which contained the offer of an independent review mechanism for nurses, midwives, and the professions supplementary to medicine, ${ }^{3}$ it was bound to excite curiosity. Furthermore, the government's response to the report's two predecessors was only partial implementation and on 9 May a general election was announced. The falling annual rate of inflation had been expected to moderate pay settlements generally and signs of an increase in white collar unemployment were being mirrored in the medical profession.

The pay bill for the medical profession (excluding the provision made for the practice expenses of independent contractors) represented, in 1982-3-at just under $£ 1200 \mathrm{~m}-$ some $8 \%$ of NHS expenditure (table I). So it is an important component of public expenditure. For just this reason the review body system embodies an assurance that the profession's remuneration will not be used as an economic regulator. In recommending increases in pay that would have added $£ 121 \mathrm{~m}$, or a little over $10 \%$, to this total the review body has abided by this "condition" in its terms of reference. Its recommendations exceeded by $£ 68 \mathrm{~m}$ the amount expressly built into NHS expenditure for pay increases in 1983-4. The government, in staging the recommendations, has saved about $£ 25 \mathrm{~m}$ of this excess, which takes its total "bite" out of medical earnings to $£ 87 \mathrm{~m}$ over the last three years. The implementation of the award in two stages will add over the year $8.1 \%$ to the pay bill, comprising $6.8 \%$ for most doctors, with more substantial gains for most junior hospital staff.

Two issues dominate the review body's 1983 considerations. These are, firstly, the manner in which the review body has reacted to the now familiar case put on behalf of hospital junior doctors for remuneration more accurately reflecting their onerous hours of duty and work, and, secondly, a detailed explanation of the way in which recommendations on general practitioner remuneration are arrived at and, by implication, translated into the fees and allowances received by general practitioners each quarter.

\section{Hospital junior staff}

Until 1970 hospital junior doctors received flat rate salaries, which bore no relation to the hours for which they were obliged to work. It was taken that the salary levels contained some element to recognise these long hours, but their relative magnitude gave grounds for disputing this assertion. The extra duty allowance system was introduced in $1970^{4}$ and was succeeded by the new contract of $1975 .{ }^{5}$ Each of these changes moved junior staff further away from a professional system of remuneration and closer to an industrial one. By 1975 the extra duty allowance system was adding an average $16 \%$ to the basic salary of, for example, a senior house officer, and by 1982 its successor-the unit of medical time-was adding 35\% (table II). This figure will now increase, in the absence of any reduction in contracted hours, to $45 \%$ by January 1984 .

British Medical Association, BMA House, Tavistock Square, London WC1H 9JP

J C FORD, head of economic research unit
TABLE I-Medical pay bills 1982-3 and 1983-4, Great Britain

\begin{tabular}{|c|c|c|c|}
\hline & $\begin{array}{l}\text { Pay bill } \\
(£ \mathrm{~m})\end{array}$ & $\begin{array}{c}\text { Cash growth } \\
(£ \mathrm{~L})\end{array}$ & $\begin{array}{l}\text { Percentage } \\
\text { growth }\end{array}$ \\
\hline $\begin{array}{l}1982-3 \text { (actual) } \\
1982-3 \text { (recommended) } \\
1983-4 \text { (actual) } \\
1983-4 \text { (recommended) }\end{array}$ & $\begin{array}{l}1181 \\
1212 \\
1277 \\
1302\end{array}$ & $\begin{array}{r}96 \\
121\end{array}$ & $\begin{array}{r}8 \cdot 1 \\
10 \cdot 2\end{array}$ \\
\hline
\end{tabular}

TABLE II-Estimated average annual remuneration of senior house officers*

\begin{tabular}{|c|c|c|c|}
\hline Year & $\begin{array}{c}\text { Basic salary } \\
(\mathscr{C})\end{array}$ & $\begin{array}{l}\text { Supplementary } \\
\text { payments } \\
(£)\end{array}$ & $\begin{array}{l}\text { Total } \\
(f)\end{array}$ \\
\hline $\begin{array}{l}1969 \\
1975 \\
1982 \text { (actual) } \\
1983 \text { (recommended) }\end{array}$ & $\begin{array}{l}1570 \\
3663 \\
7700 \\
8370\end{array}$ & $\begin{array}{r}599 \\
2731 \\
3760\end{array}$ & $\begin{array}{r}1570 \\
4262 \\
10431 \\
12130\end{array}$ \\
\hline
\end{tabular}

${ }^{*}$ Minimum scale for selected years.

The review body's recommendations must have caused io considerable problems on this occasion. The survey conducte⿳⺈. at its request by the Office of Manpower Economics can have left it in no doubt of the length and complexity of the average junior doctor's working week. The picture of the average. junior doctor that emerges shows one whose average hours ofe duty are 84 a week, who works some $66 \%$ of these hours, comprising $95 \%$ clinical and patient care-the bulk of if reported as unsupervised. The cost of paying junior doctors for such activity on an industrial basis, however, even wit premium rates considerably below those paid in such a contex: elsewhere, would be enormous and would play havoc wit/ internal relativities. The review body's solution-namely, te increase units of medical time as a percentage of basic pay fo all grades, save that of senior registrar, by a seemingly modest amount-is a short term solution. It is a step along the road te "a satisfactory structure of remuneration for junior hospital doctors."

Part of the profession's case on this occasion dealt at length with the arguments for automatic enhancements of rates of units of medical time, which would recognise increases in the intensity of work as hours of duty were reduced after agreemen? with the Health Departments on revised rota arrangements. The review body decided that it was unable to recommeno such an arrangement, and its pricing of the "overtime" arrange ments suggests that no account has been taken of possible reductions in contracted hours. The total increase in the bill fo? " $A$ " units of medical time from about $£ 75 \mathrm{~m}$ in $1982-3$ ta $£ 98 \mathrm{~m}$ in $1983-4$ (in recommended terms) includes a $16 \%$ increase over what would have occurred in the absence of anf change in the rates of pay for " $A$ " units of medical time. This figure corresponds to the weighted average for recommende increases in these rates for the grades concerned and is thus what has come to be termed "new money."

\section{General medical practitioners}

The report goes into considerable detail on the manner in which the review body reached its recommendations for generas practitioners. In the context of their remuneration the obsession of commentators for dealing in percentages is shown to its ful disadvantage. The review body recommended levels of remuneration for doctors, not the percentage increases necessary 
to achieve these levels. For salaried doctors there is usually no difficulty in reconciling the two, but for general practitioners this is rarely the case. This year's recommendations show this in stark terms. The review body recommended a fee scale that takes into account an intended average level of net remuneration and an estimate of what the average general practitioner will need to meet indirect practice expenses-that is, those not payable directly by the family practitioner committee to the practitioner incurring them. This estimate is quoted in the latest report as $£ 9290$, an increase of $£ 30$ over that cited last year. The review body has made it clear, however, that while $£ 9260$ was built into the fee scale in 1982 this was not the amount it estimated would be spent, far less what would actually be spent.

The former was, in fact, only $£ 8860$, and the latter now seems likely to be $£ 8743$. Taking this last figure as the base, the increase of $£ 547(6.3 \%)$ bears a much closer relationship to the prevailing rate of pay and price inflation than does the seemingly minuscule sum of $£ 30$.

A second problem with general practitioner remuneration lies in the lack of certainty over the amounts that the fee scale will eventually generate. The review body has set out in this year's report the figure for the gross remuneration that it was attempting to reach for the average general practitioner last year $(£ 28490)$. This figure itself contained $£ 240$ representing a once and for all correction for past underpayments and was shown to have been exceeded by some $£ 128$ when provisional figures for family practitioner committee payments became available. There are several reasons why outturn may exceed target-an increased volume of item of service work is onebut the principal cause lies in the number of general practitioners growing at a slower rate than anticipated, an effect that is most marked on capitation income.

Taking these two factors together, an increase of around $5 \%$ in the fee scale is sufficient to generate the recommended intended average gross income per general practitioner of $£ 29$ 987, and 3\% to reach the revised income payable from 1 April 1983 in the light of the government's action. Many general practitioners will find the increase in practice income that they receive hard to reconcile with the much publicised increase in net pay of $8.8 \%(6.2 \%$ with effect from 1 April), and the review body's explanation of its methodology (much vulgarised in these comments) is therefore timely. Table III compares increases in average fees and allowances in recent years with "notional" increases in recommended gross and net remuneration.

\section{Other crafts}

Other groups of doctors may discover recommendations to welcome and deprecate in the thirteenth report. Consultants will no doubt be pleased to see that no further move has been made to average out fee income and treat this as a common element of salary. The incidence of such income is variable
TABLE III-Percentage increase in average fees and allowances compared with "notional" increases in recommended gross and net remuneration

\begin{tabular}{lccc}
\hline Year & $\begin{array}{c}\text { Gross } \\
\text { remuneration } \\
\left({ }^{\circ}, 1\right)\end{array}$ & $\begin{array}{c}\text { Net } \\
\text { remuneration } \\
\left({ }^{\circ}(1)\right.\end{array}$ & $\begin{array}{c}\text { Fees and } \\
\text { allowances } \\
\left({ }^{\prime}(1)\right.\end{array}$ \\
\hline 1979 & $21 \cdot 5$ & $26 \cdot 0$ & $18 \cdot 0$ \\
1980 & $30 \cdot 5$ & $32 \cdot 1$ & $30 \cdot 1$ \\
1981 & $11 \cdot 2$ & $6 \cdot 0$ & $12 \cdot 4$ \\
1982 & $7 \cdot 6$ & $5 \cdot 7$ & $9 \cdot 2$ \\
1983 (recommended) & $6 \cdot 1$ & $8 \cdot 8$ & $4 \cdot 8$ \\
\hline
\end{tabular}

across specialties to such an extent that this step, much feared as a result of comments in earlier reports, could only be counterproductive. They will similarly be pleased that the value of distinction awards is maintained in relation to the basic scale, notwithstanding their concern at past tendencies to relative devaluation.

Ophthalmic medical practitioners seem to have fared less well, with increases in net remuneration well below those of other grades. The profession has long argued that the assumptions used by the review body on timing are unreasonable and that the comparators cited by the Health Departments are inappropriate. The review body has urged a new timing study on the two parties, the last having taken place in 1975, and the results of this may well lead the review body to rethink its recommendations in the future.

Community medicine trainees gave detailed evidence to the review body on relative remuneration in the light of a survey by the Office of Manpower Economics into the pattern of their work. While no change has been recommended in their basic salary levels vis à vis those of their hospital colleagues, the value of their out of hours supplement has been relatively reduced by the award made to hospital junior staff for units of medical time payments. The profession and the Health Departments have been urged to reach agreement on revised contractual arrangements, and the review body will probably look more closely at the position when it comes to price the outcome of any such discussions.

The impact of the 1983 report on the profession will not be reflected in the country at large, where the concern will be limited to comparisons of the crude percentage increases with those rises obtained by other groups. The review body's concern with matters of detail affecting all aspects of medical remuneration is eminently shown in the thirteenth report, and, for this reason alone, it justifies more intensive study.

\section{References}

1 Review Body on Doctors' and Dentists' Remuneration. Thirteenth report 1983. Cmnd 8878. London: HMSO, 1983.

2 Macintyre D. NHS dispute collapses in 90 minutes of talks. The Times 1982 Dec 16:1

${ }^{3}$ Anonymous. Review body for nurses and allied staff. $\mathrm{Br}$ Med $\mathcal{J}$ 1983; $286: 1370$.

${ }^{4}$ Anonymous. Pay for off-duty work. $B r$ Med $\mathcal{F} 1969$;iii, suppl:7.

5 Anonymous. Junior doctors' contract. Br Med $\mathcal{f}$ 1975;iv:719-20.
Medical school intake-continued from page 1837

trols or any written reply from the government. After four years he thought that at least there should be something on paper.

Dr M Hamid Husain supported the policy. He believed that any attempts by the committee either to freeze or to reduce the intake of students to medical schools without making efforts to control the entry of graduates from overseas would be resented by the profession and the public. Decision making was becoming more difficult and that was why it was as much in the interests of overseas doctors as in the interests of the host country that the probem was tackled. Dr Husain wanted the association to make a firm commitment that it should not simply seek to regulate the entry of doctors but should also take active measures to guide overseas doctors who were already here into suitable training and career opportunities.

The proposal and the following one were adopted:

"That urgent discussions be initiated with the General Medical Council and Health
Departments to identify and mitigate the problems of those doctors with limited registration who are unable to achieve full registration."

Dr Wilson explained that limited registration enabled doctors to practise in approved posts for five years. At the end of that time they could proceed to full registration provided that they had acquired a certain seniority in the profession such as a registrar post. So far as he was aware the General Medical Council had not publicised the criteria that would determine whether a doctor would achieve full registration or not. 